\title{
Virgisporangium aliadipatigenens sp. nov., Isolated from Soil in Iriomote Island and Emended Description of the Genus Virgisporangium
}

\author{
Misa Otoguro $^{1 *}$, Yuumi Ishida ${ }^{1}$, Tomohiko Tamura ${ }^{1}$, Hideki Yamamura ${ }^{2}$, \\ Ken-ichiro Suzuki ${ }^{1}$, and Masayuki Hayakawa ${ }^{2}$ \\ ${ }^{1}$ National Institute of Technology and Evaluation (NITE) Biological Resource Center (NBRC), \\ Department of Biotechnology, NITE, 2-5-8 Kazusakamatari, Kisarazu, Chiba 292-0818, Japan \\ ${ }^{2}$ Division of Applied Biological Sciences, Interdisciplinary Graduate School of Medicine and Engineering, \\ University of Yamanashi, 4-3-11 Takeda, Kofu 400-8511, Japan
}

(Received Mar. 30, 2010 / Accepted Aug. 6, 2010 / Published Nov. 12, 2010)

\begin{abstract}
During a study of the distribution of actinomycetes in a subtropical zone in Japan, two strains forming short sporangiophores on the substrate mycelium were isolated from soil. The 16S rRNA gene sequences of the isolates indicated that these organisms formed a monophyletic cluster with members of the genus Virgisporangium in the family Micromonosporaceae. These strains formed narrow sporangia on short sporangiophores directly above the substrate mycelium. The sporangia contained motile spores. The strains contained 3-OH-diaminopimelic acid in the cell wall and glucose, ribose, mannose, galactose, xylose and 3-O-methylmannose as whole-cell sugars. The predominant menaquinones were $\mathrm{MK}-10\left(\mathrm{H}_{4}\right)$ and MK10( $\left.\mathrm{H}_{6}\right)$. The diagnostic phospholipid was phosphatidylethanolamine. Cis $9 \mathrm{C}_{17: 1}$ and $\mathrm{C}_{17: 0}$ were detected as the major cellular fatty acids. The G+C content of the DNA was $71.7 \mathrm{~mol} \%$. DNA-DNA relatedness analysis showed that the two isolates represented the same genomic species. The results of morphological, chemotaxonomic and 16S rRNA gene sequence analyses, as well as DNA-DNA hybridization studies, confirmed that these isolates certainly belonged to a new species of the genus Virgisporangium. We propose a novel taxon of the genus Virgisporangium as Virgisporangium aliadipatigenens sp. nov., with the type strain $\operatorname{IR20-55}^{\mathrm{T}}$ (= NBRC 105644 ${ }^{\mathrm{T}}$ ).
\end{abstract}

\section{INTRODUCTION}

The genus Virgisporangium was firstly described by Tamura et al. (2001) for actinomycete strains that are characterized by motile spores, and contain 3-OH-diaminopimelic acid $\left(3-\mathrm{OH}-\mathrm{A}_{2} \mathrm{pm}\right)$ in the cell wall and 3$O$-methylmannose as a whole-cell sugar. The original spelling Virgosporangium was corrected by the List Editor of the International Journal of Systematic and Evolutionary Microbiology (2001). This genus currently contains only two species, namely, Virgisporangium ochraceum and Virgisporangium aurantiacum, both of which were isolated in Japan.

During studies of the inventories of actinomycetes from a subtropical area of Japan, strains IR20-55 ${ }^{\mathrm{T}}$ and IR0825 were isolated from soil in Iriomote island, Okinawa, Japan, using the rehydration and centrifugation method (Hayakawa et al., 2000), a highly selective isolation method for motile actinomycetes. Comparative 16S rRNA gene sequence analysis revealed that these resided in the family Micromonosporaceae and were closely related to the genus Virgisporangium. Their phenotypic and phylo- genetic characteristics, coupled with data on genomic DNA-DNA relatedness, suggested that these strains should be classified as a novel species. Accordingly, we propose the name Virgisporangium aliadipatigenens sp. nov. for strains IR20-55 ${ }^{\mathrm{T}}$ and IR08-25.

\section{MATERIALS AND METHODS}

Strains IR20-55 ${ }^{\mathrm{T}}$ and IR08-25 were isolated from soil collected in Iriomote Island, Japan using the rehydration and centrifugation method (Hayakawa et al., 2000) with humic acid-vitamin (HV) agar (Hayakawa \& Nonomura, 1987) supplemented with cycloheximide $\left(50 \mathrm{mg} \mathrm{l}^{-1}\right)$ and nalidixic acid $\left(20 \mathrm{mg} \mathrm{l}^{-1}\right)$. After aerobic incubation at $28^{\circ} \mathrm{C}$ for 3 weeks, colonies were transferred and purified on yeast extract-starch (YS) agar (2 $\mathrm{g}$ yeast extract, $10 \mathrm{~g}$ soluble starch and $\left.15 \mathrm{~g}_{\text {agar }} \mathrm{1}^{-1} ; \mathrm{pH} 7.3\right)$.

The morphological features of the strains grown on YS medium or HV agar were observed by light and scanning electron microscope (model JSM-6060; JEOL). For electron microscopy, agar blocks containing microbial growth were fixed with $1 \%$ osmium tetroxide, dehydrated through

\footnotetext{
*Correspondence: Misa Otoguro, National Institute of Technology and Evaluation (NITE) Biological Resource Center (NBRC), Department of Biotechnology, NITE, 2-5-8 Kazusakamatari, Kisarazu, Chiba 292-0818, Japan; Phone: +81-438-20-5763; Fax: +81438-52-2329. E-mail: otoguro-misa@nite.go.jp
} 
a graded series of ethanol and isoamyl acetate and criticalpoint-dried. The gold-coated specimens were then observed using a scanning electron microscope. The motility of the spores was observed under a light microscope using cells grown on $\mathrm{HV}$ agar at $28^{\circ} \mathrm{C}$ for 21 days. Spore suspensions were obtained from the agar surface and mixed with phosphate buffer (K-salts; $0.01 \mathrm{M}, \mathrm{pH} 7.0$ ) containing $10 \%$ soil extract (Henrich, 1947) and incubated at $30^{\circ} \mathrm{C}$ for 1 hour.

The physiological characteristics and the growth range for temperatures and $\mathrm{pH}$ values were tested on YS broth. The cultural and biochemical characteristics were examined using methods described previously (Gordon et al., 1974; Shirling \& Gottlieb, 1966; Williams et al., 1983). The colours of the colonies were determined according to a Mycological Color Chart (Rayner, 1970). The utilization of carbohydrates as sole carbon sources was tested using ISP medium 9 (Difco) containing $0.1 \%$ yeast extract and B-vitamins (Hayakawa \& Nonomura, 1987) as a basal medium. API ZYM and API Coryne tests (bioMérieux) were used according to the manufacturer's protocol to determine the physiological and biochemical characteristics of the strains.

Freeze-dried cells for chemotaxonomic studies were obtained from cultures grown in YS broth on a rotary shaker at $200 \mathrm{rpm}$ at $28^{\circ} \mathrm{C}$ for 5 days. The $\mathrm{A}_{2} \mathrm{pm}$ isomers and sugars of whole-cell hydrolysates were analysed using procedures described by Hasegawa et al. (1983) and Schaal (1985), respectively. Polar lipids were extracted and identified by two-dimensional TLC using methods described by Minnikin et al. (1984). Isoprenoid quinones were extracted and purified by the method of Minnikin et al. (1984) and determined by LC-MS. The cellular fatty acid composition was determined using the Microbial Identification System (MIDI Inc.). Identification and quantification of the peaks was performed using GC-MS. The N-acyl group of muramic acid in peptidoglycan was determined according to the method of Uchida et al. (1999).

Genomic DNA was obtained using the method of Saito \& Miura (1963). The $\mathrm{G}+\mathrm{C}$ content of the DNA was determined by HPLC as described by Tamura et al. (1994). DNA-DNA hybridization was performed fluorometrically using photobiotin-labelled probes in microplate wells as described by Ezaki et al. (1989).

The 16S rRNA gene was amplified by PCR and sequenced following the procedures described by Tamura \& Hatano (2001) using an ABI PRISM 3730 Genetic Analyzer using the BigDye Terminator v3.1 Cycle Sequencing Kit (Applied Biosystems). The DDBJ accession numbers for the 16S rRNA gene sequences of strains IR20-55 $5^{\mathrm{T}}$ and IR08-25 are AB548616 and AB548617, respectively. The 16S rRNA gene sequences obtained in the present study were aligned with the sequences of the species with validly published names from the family Micromonosporaceae that were available from the GenBank/ EMBL/DDBJ by using the MEGA (Molecular Evolu- tionary Genetics Analysis) version 3.1 (Kumar et al., 2004) and CLUSTAL_X (Thompson et al., 1997) programs. A phylogenetic tree was constructed using the neighbourjoining tree algorithm (Saitou \& Nei, 1987), maximumlikelihood (Felsenstein, 1981) and maximum parsimony (Fitch, 1971) methods. The resultant neighbour-joining tree topology was evaluated by bootstrap analysis with 1000 replicates (Felsenstein, 1985).

\section{RESULTS AND DISCUSSION}

Strains IR20-55 $5^{\mathrm{T}}$ and IR08-25 formed short sporangiophores and narrow sporangia on these sporangiophores directly above the surface of the substrate mycelium (Fig. 1). Several spores were present per sporangium. Strains IR20-55 ${ }^{\mathrm{T}}$ and IR08-25 produced oval to short rods $(0.6-0.9$ by $0.8-1.4 \mu \mathrm{m})$ spores. The spores exhibited motility when suspended in sterile distilled water or potassium phosphate buffer $(0.01 \mathrm{M}, \mathrm{pH} 7.0)$. The sporangia were well-developed on $\mathrm{HV}$ agar. The strains produced a pale sienna soluble pigment on ISP medium 7 (Table 1). Growth occurred at $20-37^{\circ} \mathrm{C}$ but not at $15^{\circ} \mathrm{C}$. Optimal growth was observed at $28-37^{\circ} \mathrm{C}$. The $\mathrm{pH}$ range for growth was 7.0-9.0. The strains did not grow at a $\mathrm{NaCl}$ concentration higher than $2 \%$. Both strains utilized glucose, sucrose, galactose and mannose. Only strain IR20-55 utilized D-fructose, maltose and xylose, and only strain IR08-25 utilized L-arabinose. The isolates were positive for starch hydrolysis. Other physiological and biochemical characteristics are shown in Table 2 and in the species description.

Cell wall analysis by HPLC and TLC indicated that the strains contained 3-OH- $\mathrm{A}_{2} \mathrm{pm}$. The whole-cell sugars were glucose, mannose, galactose, xylose and 3-O-methylmannose. The predominant menaquinones of strain IR20-55

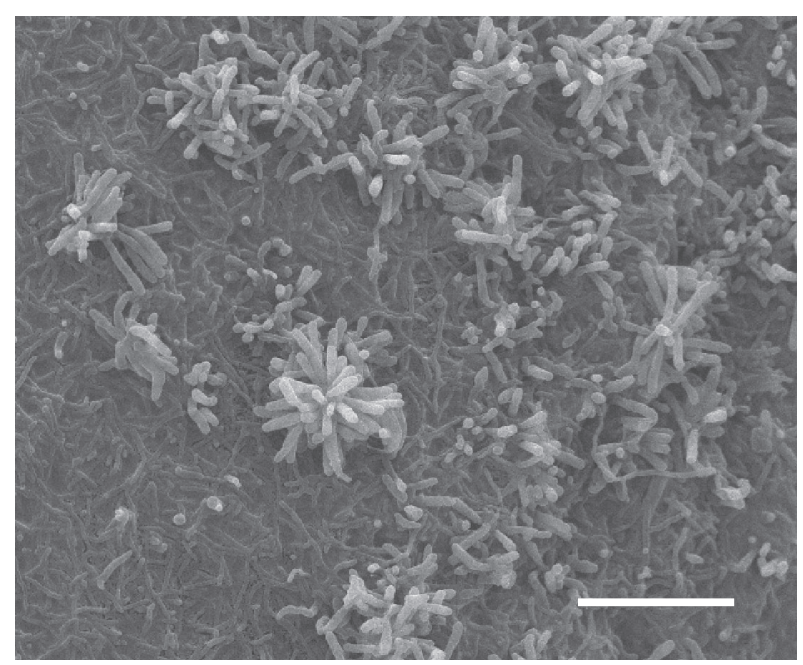

Fig. 1. Scanning electron micrographs of isolate IR20-55 grown on $\mathrm{HV}$ agar for 3 weeks at $28^{\circ} \mathrm{C}$. Bar, $10 \mu \mathrm{m}$. 
Table 1. Cultural characteristics of isolates IR20-55 $5^{\mathrm{T}}$ and IR0825 .

\begin{tabular}{|c|c|c|}
\hline & IR20-55 & IR08-25 \\
\hline \multicolumn{3}{|l|}{ ISP2 } \\
\hline Growth & Weak & Weak \\
\hline Reverse colour & Orange (7) & Luteus (12) \\
\hline $\begin{array}{l}\text { Soluble pigment } \\
\text { ISP3 }\end{array}$ & Absent & Absent \\
\hline Growth & Good & Good \\
\hline Reverse colour & Luteus (12) & Luteus (12) \\
\hline $\begin{array}{l}\text { Soluble pigment } \\
\text { ISP4 }\end{array}$ & Absent & Absent \\
\hline Growth & Good & Good \\
\hline Reverse colour & Orange (7) & Luteus (12) \\
\hline $\begin{array}{l}\text { Soluble pigment } \\
\text { ISP5 }\end{array}$ & Absent & Absent \\
\hline Growth & Good & Good \\
\hline Reverse colour & Orange (7) & Pale luteus (11) \\
\hline $\begin{array}{l}\text { Soluble pigment } \\
\text { ISP6 }\end{array}$ & Absent & Absent \\
\hline Growth & Weak & Weak \\
\hline Reverse colour & Luteus (12) & Luteus (12) \\
\hline $\begin{array}{l}\text { Soluble pigment } \\
\text { ISP7 }\end{array}$ & Absent & Absent \\
\hline Growth & Good & Good \\
\hline Reverse colour & Umber (9) & Umber (9) \\
\hline $\begin{array}{l}\text { Soluble pigment } \\
\text { YS }\end{array}$ & Weak sienna (8) & Weak sienna (8) \\
\hline Growth & Good & Good \\
\hline Reverse colour & Luteus (12) & Luteus (12) to sienna (8) \\
\hline Soluble pigment & Absent & Absent \\
\hline
\end{tabular}

The colour codes in parentheses correspond to the colour code in A Mycological Colour Chart (Rayner, 1970).

Aerial mycelium of the isolates was not observed on the media used in this study.

were MK-10 $\left(\mathrm{H}_{4}\right)$, MK-10( $\left.\mathrm{H}_{6}\right)$ and MK-10 $\left(\mathrm{H}_{8}\right)$. The predominant menaquinone of IR08-55 was MK-10 $\left(\mathrm{H}_{4}\right)$, with small amounts of MK-10( $\left.\mathrm{H}_{6}\right)$ and MK-10 $\left(\mathrm{H}_{8}\right)$. Mycolic acids were absent. Phosphatidylethanolamine was detected as a diagnostic phospholipid, but other major polar phospholipids were not detected. The acyl type of the cell wall polysaccharides was glycolyl. The $\mathrm{G}+\mathrm{C}$ contents of the DNAs of the two strains were $71.7 \mathrm{~mol} \%$. The major fatty acids of the isolates were cis $9 \mathrm{C}_{17: 1}$ (34.6-39.8\%) and $\mathrm{C}_{17: 0}(21.8-25.3 \%)$, as identified by GC-MS and the retention times of GC analysis. The predominant cellular fatty acids were different from the two known species (Table 3).

Almost complete gene sequences for the 16S rRNA genes of strains IR20-55 ${ }^{\mathrm{T}}$ and IR08-25 were determined. Phylogenetic analysis revealed that the isolates were affiliated within the cluster of the genus Virgisporangium (Fig. 2). The similarity values of the 16S rRNA gene sequences
Table 2. Differential phenotypic properties of the isolates IR20$55^{\mathrm{T}}$, IR08-25 and the type strains of phylogenetically related Virgisporangium species.

\begin{tabular}{|c|c|c|c|c|}
\hline Characteristic & 1 & 2 & 3 & 4 \\
\hline \multicolumn{5}{|l|}{ Growth on sole carbon sources: } \\
\hline D-Fructose & + & - & + & + \\
\hline D-Mannitol & - & - & + & + \\
\hline L-Arabinose & - & + & + & + \\
\hline Glycerol & + & - & + & + \\
\hline Inositol & - & - & + & - \\
\hline D-Sorbitol & - & - & + & - \\
\hline Lactose & - & - & - & + \\
\hline Melibiose & - & - & + & + \\
\hline Maltose & + & - & + & + \\
\hline Xylose & + & - & + & + \\
\hline \multicolumn{5}{|l|}{ Growth in } \\
\hline $\mathrm{NaCl} 2 \%$ & - & - & + & + \\
\hline Assimilation of calcium malate & + & - & - & - \\
\hline Nitrate reduction & - & ++ & + & + \\
\hline \multicolumn{5}{|l|}{ Growth at } \\
\hline $15^{\circ} \mathrm{C}$ & - & - & + & + \\
\hline $37^{\circ} \mathrm{C}$ & ++ & ++ & + & - \\
\hline Peptonization of Milk & - & - & + & + \\
\hline \multicolumn{5}{|l|}{ API ZYM: } \\
\hline Alkaline phosphatase & + & w & + & + \\
\hline Esterase (C-4) & - & w & $\mathrm{w}$ & $\mathrm{w}$ \\
\hline Trypsin & + & - & + & + \\
\hline Chymotrypsin & - & + & + & + \\
\hline Acid phosphatase & + & - & - & $\mathrm{w}$ \\
\hline$\alpha$-Galactosidase & + & - & - & $\mathrm{w}$ \\
\hline$N$-Acetyl- $\beta$-glucosaminidase & - & - & + & + \\
\hline
\end{tabular}

Strains indicated as: 1 , IR20-55 ${ }^{\mathrm{T}} ; 2$, IR08-25; 3 , V. ochraceum NBRC $10618^{\mathrm{T}} ; 4, V$. aurantiacum NBRC $16421^{\mathrm{T}}$. + , positive; - , negative; w, weakly positive.

Data were taken from present study and Tamura et al. (2001).

between the isolates and the type strains of validated Virgisporangium species were $97.0-97.5 \%$. The sequence similarity between the isolates IR20-55 $5^{\mathrm{T}}$ and IR08-25 was 99.8\%. Signature nucleotides of the genus Virgisporangium at positions 502-543 (A-U) and 1116-1184 (U-G) (Tamura et al., 2001) were present in the 16S rRNA gene sequences of strains IR20-55 and IR08-25. The DNADNA relatedness values between strains IR20-55 $5^{\mathrm{T}}$ and IR08-25 were 81 and $106 \%$, indicating that the two strains belong to one species. The values ranged from $6 \%$ to $21 \%$ for DNA-DNA relatedness between strain IR20-55 $5^{\mathrm{T}}$ and Virgisporangium ochraceum NBRC $16418^{\mathrm{T}}$ and Virgisporangium aurantiacum $\mathrm{NBRC} 16421^{\mathrm{T}}$.

On the basis of the results of phylogenetic, chemotaxonomic, physiological and biochemical analysis and DNA-DNA hybridization tests, we propose a novel Virgisporangium species, namely, Virgisporangium aliadipatigenens sp. nov. for strains IR20-55 ${ }^{\mathrm{T}}$ and IR08-25. 
Table 3. Cellular fatty acid composition (\%) of isolates IR20-55 $5^{\mathrm{T}}$, IR08-25, Virgisporangium ochraceum $\mathrm{NBRC}^{16418^{\mathrm{T}}}$ and Virgisporangium aurantiacum NBRC $16421^{\mathrm{T}}$

\begin{tabular}{|c|c|c|c|c|}
\hline Fatty acid & $\operatorname{IR20-55^{T}}$ & IR08-25 & 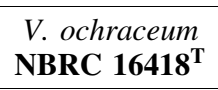 & $\begin{array}{l}\text { V. aurantiacum } \\
{\text { NBRC } \mathbf{1 6 4 2 1}^{\mathrm{T}}}^{\text {NB }}\end{array}$ \\
\hline iso- $\mathrm{C}_{14: 0}$ & - & - & 0.7 & 1.3 \\
\hline $\mathrm{C}_{14: 0}$ & - & - & - & 0.4 \\
\hline iso- $\mathrm{C}_{15: 0}$ & 1.0 & 2.3 & 3.4 & 6.2 \\
\hline anteiso- $\mathrm{C}_{15: 0}$ & 0.6 & - & 0.9 & 2.6 \\
\hline $\mathrm{C}_{15: 0}$ & 4.2 & 1.6 & 0.8 & 0.5 \\
\hline iso- $\mathrm{C}_{16: 1} \mathrm{G}$ & - & - & - & 1.9 \\
\hline iso- $\mathrm{C}_{16: 1} \mathrm{H}$ & - & - & 0.7 & - \\
\hline iso- $\mathrm{C}_{16: 0}$ & 7.3 & 5.2 & 40.1 & 41.54 \\
\hline cis $9-\mathrm{C}_{16: 1}$ & 1.1 & 2.1 & - & - \\
\hline anteiso- $\mathrm{C}_{15: 0} 2-\mathrm{OH}$ & - & - & 0.9 & - \\
\hline $\mathrm{C}_{16: 0}$ & 3.1 & 6.6 & 1.5 & 1.8 \\
\hline $\mathrm{C}_{16: 0}$ 9-methyl? & - & 1.0 & - & 0.7 \\
\hline anteiso- $\mathrm{C}_{17: 1} \mathrm{C}$ & 0.6 & - & - & 1.3 \\
\hline iso- $\mathrm{C}_{17: 0}$ & 1.0 & 3.7 & 3.3 & 2.8 \\
\hline anteiso- $\mathrm{C}_{17: 0}$ & 4.9 & 3.0 & 13.2 & 18.4 \\
\hline cis $9-\mathrm{C}_{17: 1}$ & 39.8 & 34.6 & 8.1 & 2.8 \\
\hline $\mathrm{C}_{17: 0}$ & 25.3 & 21.8 & 4.7 & 2.7 \\
\hline 10-methyl $C_{17: 0}$ & 1.0 & 0.9 & 0.9 & - \\
\hline iso- $\mathrm{C}_{18: 0}$ & 0.5 & 0.4 & 1.2 & 0.8 \\
\hline cis $9-\mathrm{C}_{18: 1}$ & 4.6 & 10.3 & 13.1 & 8.2 \\
\hline iso- $\mathrm{C}_{17: 0} 2-\mathrm{OH}$ & - & - & - & 1.2 \\
\hline Summes Feature 7 & 0.9 & 1.8 & - & - \\
\hline $\mathrm{C}_{18: 0}$ & 1.6 & 3.0 & 1.3 & 1.5 \\
\hline Sum in feature 8 & - & - & 5.0 & 1.3 \\
\hline Sum in feature 9 & - & - & - & 2.4 \\
\hline
\end{tabular}

Data were taken from the present study. Values are percentage of total fatty acids. - , not detected.

Fatty acid identities were determined from the Microbial Identification System software (MIDI Inc.) peak-naming table.

\section{Emended description of Virgisporangium Tamura et al. 2001}

The following features are added to those given in the current description of Virgisporangium by Tamura et al. (2001). The major fatty acids are iso- $\mathrm{C}_{16: 0}$ and anteiso$\mathrm{C}_{17: 0}$, or cis $9-\mathrm{C}_{17: 1}$ and $\mathrm{C}_{17: 0}$. The $\mathrm{G}+\mathrm{C}$ content of the genomic DNA is $71-72 \mathrm{~mol} \%$.

\section{Description of Virgisporangium aliadipatigenens sp. nov.}

Virgisporangium aliadipatigenens (a.li.a.di.pa.ti.ge'nens. L. adj. and pronoun alius, other, another, different; N.L. n. acidum adipatum, fatty acid; L. part. adj. genens, producing; N.L. part. adj. aliadipatigenens, producing different fatty acids)

Gram-positive, non-acid-fast and aerobic bacterium with branching hyphae. The sporangia were well-developed on HV agar. Non-fragmenting orange to luteus coloured substrate mycelia are present. Light brown soluble pigment is produced on tyrosine agar (ISP medium 7). Slender sporangia are formed on short sporangiophores on the substrate mycelium. Several spores are present per sporangium, and the spores are oval to short rods $(0.6-0.9$ by $0.8-$
$1.5 \mu \mathrm{m})$; they are motile when suspended in sterile distilled water or potassium phosphate buffer $(0.01 \mathrm{M}, \mathrm{pH} 7.0)$. Growth occurs between $\mathrm{pH} 7$ and 9 , and $20^{\circ} \mathrm{C}$ and $37^{\circ} \mathrm{C}$. Does not grow in $2 \% \mathrm{NaCl}$. Nitrate reduction is a variable property. Starch hydrolysis is positive. Gelatin liquefaction, milk peptonization and urea hydrolysis are negative. Glucose, sucrose, galactose and mannose are utilized, but D-mannitol, inositol, D-sorbitol, lactose and melibiose are not. Leucine arylamidase, $\beta$-galactosidase and $\alpha$-glucosidase were detected by the API ZYM enzyme assay; lipase (C-14), valine arylamidase, cysteine arylamidase, $\beta$-glucuronidase, $\mathrm{N}$-acetyl- $\beta$-glucosaminidase, $\alpha$-mannosidase and $\alpha$-fucosidase are negative. The major cellular fatty acids are cis $9 \mathrm{C}_{17: 1}$ and $\mathrm{C}_{17: 0}$. The $\mathrm{G}+\mathrm{C}$ content of the DNA is $71.7 \mathrm{~mol} \%$. The type strain is IR $20-55^{\mathrm{T}}$ (= NBRC $105644^{\mathrm{T}}$ ), which was isolated from the soil in a sugarcane field in Iriomote Island, Japan.

\section{ACKNOWLEDGEMENTS}

We are grateful to Dr Jean P. Euzéby (Société de Bactériologie Systématique et Vétérinaire and Ecole 


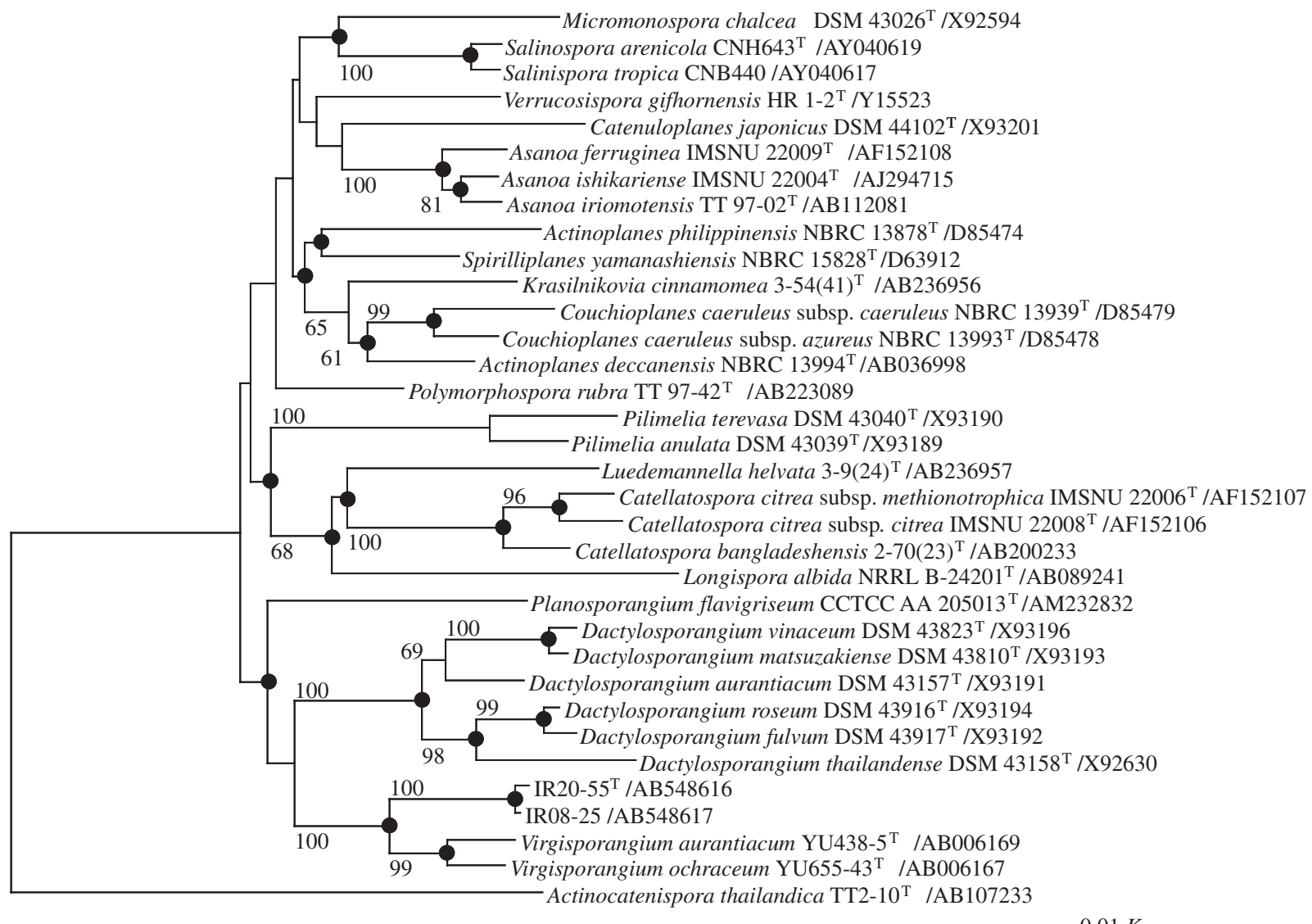

$$
0.01 K_{\text {nuc }}
$$

Fig. 2. Phylogenetic tree based on $16 \mathrm{~S}$ rRNA gene sequences showing the relationship of strains IR20-55 $5^{\mathrm{T}}$ and IR08-25 to the family Micromonosporaceae. The tree was constructed using the neighbour-joining method and $K_{\text {nuc }}$ values (Saitou \& Nei, 1987). Actinocatenispora thailandica $\mathrm{TT} 2-10^{\mathrm{T}}(\mathrm{AB} 107233)$ was used as an out-group. The numbers at branch nodes represent bootstrap percentages (1000 resamplings; only values over 50\% are given). Dots indicate that the corresponding nodes were also recovered in the tree generated with the maximum-parsimony algorithm. Bar, $0.01 \mathrm{~K}_{\text {nuc }}$.

Nationale Vétérinaire de Toulouse, France) for support with the nomenclature. This study was supported in part by a research grant from the Institute for Fermentation, Osaka (IFO), Japan.

\section{REFERENCES}

Ezaki, T., Hashimoto, Y. \& Yabuuchi, E. (1989). Fluorometric deoxyribonucleic acid-deoxyribonucleic acid hybridization in microdilution wells as an alternative to membrane filter hybridization in which radioisotopes are used to determine genetic relatedness among bacterial strains. Int. J. Syst. Bacteriol. 39, 224-229.

Felsenstein, J. (1981). Evolutionary trees from DNA sequences: a maximum likelihood approach. J. Mol. Evol. 17, 368-376.

Felsenstein, J. (1985). Confidence limits on phylogenies: an approach using the bootstrap. Evolution 39, 783-791.

Fitch, W. M. (1971). Toward defining the course of evolution: minimum change for a specific tree topology. Syst. Zool. 20, 406-416.
Gordon, R. E., Barnett, D. A., Handerhan, J. E. \& Pang, C. H.-N. (1974). Nocardia coeliaca, Nocardia autotrophica, and the nocardin strain. Int. J. Syst. Bacteriol. 24, 54-63.

Hasegawa, T., Takizawa, M. \& Tanida, S. (1983). A rapid analysis for chemical grouping of aerobic actinomycetes. $J$. Gen. Appl. Microbiol. 29, 319-322.

Hayakawa, M. \& Nonomura, H. (1987). Humic acid-vitamin agar, a new medium for the selective isolation of soil actinomycetes. J. Ferment. Technol. 65, 501-509.

Hayakawa, M., Otoguro, M., Takeuchi, T., Yamazaki, T. \& Iimura, Y. (2000). Application of a method incorporating differential centrifugation for selective isolation of motile actinomycetes in soil and plant litter. Antonie van Leeuwenhoek 78, 171-185.

Henrich, A. T. (1947). Methods for studying molds, yeasts, and actinomycetes. In Molds, Yeasts and Actinomycetes ed. Skinner C.E., Emmons C.W. and Tsuchiya H.M. pp49-80. New York: Eiley and Sons.

Kumar, S., Tamura, K. \& Nei, M. (2004). MEGA3: Integrated software for Molecular Evolutionary Genetics Analysis and sequence alignment. Briefings in Bioinformatics 5, 150-163. 
LIST EDITOR, IJSEM. (2001). Notification that new names and new combinations have appeared in volume 51 , part 5 , of the IJSEM. Int. J. Syst. Evol. Microbiol. 51, 1947-1948.

Minnikin, D. E., O’Donnell, A. G., Goodfellow, M., Alderson, G., Athalye, M., Schaal, A. \& Parlett, J. H. (1984). An integrated procedure for the extraction of bacterial isoprenoid quinones and polar lipids. J. Microbiol. Methods 2, 233-241.

Rayner, R. W. (1970). A mycological colour Chart. Kew, Surrey: Commonwealth Mycological Institute.

Saito, H. \& Miura, K. (1963). Preparation of transforming deoxyribonucleic acid by phenol treatment. Biochim. Biophys. Acta 72, 619-629.

Saitou, N. \& Nei, M. (1987). The neighbor-joining method: a new method for reconstructing phylogenetic trees. Mol. Biol. Evol. 4, 406-425.

Schaal, K. P. (1985). Identification of clinically significant actinomycetes and related bacteria using chemical techniques. In Chemical methods in Bacterial Systematics, pp. 359-381. Edited by M. Goodfellow \& D. E. Minnikin. London: Academic Press.

Shirling, E. B. \& Gottlieb, D. (1966). Methods for characterization of Streptomyces species. Int. J. Syst. Bacteriol. 16, 313340.

Tamura, T., Nakagaito, Y., Nishii, T., Hasegawa, T., Stackebrandt, E. \& Yokota, A. (1994). A new genus of the order Actinomycetales, Couchioplanes gen. nov., with descrip- tions of Couchioplanes caeruleus (Horan and Brodsky 1986) comb. nov. and Couchioplanes caeruleus subsp. azureus subsp. nov. Int. J. Syst. Bacteriol. 44, 193-203.

Tamura, T. \& Hatano, K. (2001). Phylogenetic analysis of the genus Actinoplanes and transfer of Actinoplanes minutisporangius Ruan et al. 1986 and 'Actinoplanes aurantiacus' to Cryptosporangium minutisporangium comb. nov. and Cryptosporangium aurantiacum sp. nov. Int. J. Syst. Evol. Microbiol. 51, 2119-2125.

Tamura, T., Hayakawa, M. \& Hatano, K. (2001). A new genus of the order Actinomycetales, Virgosporangium gen. nov., with descriptions of Virgosporangium ochraceum sp. nov. and Virgosporangium aurantiacum sp. nov. Int. J. Syst. Evol. Microbiol. 51, 1809-1816.

Thompson, J. D., Gibson, T. J., Plewniak, F., Jeanmougin, F. \& Higgins, D. G. (1997). The CLUSTAL $X$ windows interface: flexible strategies for multiple sequence alignment aided by quality analysis tools. Nucleic Acids Res. 25, 4876-4882.

Uchida, K., Kudo, T., Suzuki, K. \& Nakase, T. (1999). A new rapid method of glycolate test diethyl ether extraction, which is applicable to a small amount of bacterial cells of less than one milligram. J. Gen. Appl. Microbiol. 45, 49-56.

Williams, S. T., Goodfellow, M., Alderson, G., Wellington, E. M., Sneath, P. H. \& Sackin, M. J. (1983). Numerical classification of Streptomyces and related genera. J. Gen. Microbiol. 129, 1743-1813. 